\title{
Reproductive ecology of the ascidian Cnemidocarpa verrucosa at Potter Cove, South Shetland Islands, Antarctica
}

\author{
Ricardo Sahade $^{1, *}$, Marcos Tatián ${ }^{1}$, Graciela B. Esnal ${ }^{2}$ \\ ${ }^{1}$ Departamento de Diversidad y Ecología, Ecología Marina, Facultad de Ciencias Exactas Físicas y Naturales, \\ Universidad Nacional de Córdoba, CONICET, Av Vélez Sársfield 299, 5000 Córdoba, Argentina \\ ${ }^{2}$ Departamento de Ciencias Biológicas, Facultad de Ciencias Exactas y Naturales, Universidad de Buenos Aires, \\ CONICET, 1428 Buenos Aires, Argentina
}

\begin{abstract}
The reproductive biology of the common Antarctic ascidian Cnemidocarpa verrucosa (Lesson) (Tunicata, Ascidiacea) was studied in a shallow-water population at Potter Cove, South Shetland Islands. Samples were taken monthly by SCUBA diving over a 15 mo period during 1996 and 1997. The reproductive cycle was examined by histological analysis of the gonads and gonad index measurements. Mean oocyte diameter peaked in June and showed a sharp decrease in August. A similar pattern was exhibited by gonad indices, which suggests a strong seasonality in reproduction. Gametogenesis was continuous year-round, although vitellogenesis, mature oocytes and mature spermatocytes were mainly observed during the austral winter. It is interesting that reproduction of this suspension feeder seems to be decoupled from the pulses of primary production characteristics of Antarctic systems and was not related to the slight, but present, temperature changes. It was striking since these 2 factors are usually among the most important in determining reproductive cycles, especially in suspension feeders. This suggests either that winter time is not so stressful, in energetic terms, at least in the Potter Cove ecosystem, or that this ascidian species is able to store energy in some organs during favorable periods to later fuel reproduction. This later idea is supported by the higher gonad production observed in 1997 compared to 1996, which coincided with higher levels of chl a that year.
\end{abstract}

KEY WORDS: Antarctica $\cdot$ Ascidians $\cdot$ Reproductive strategies $\cdot$ Cnemidocarpa Resale or republication not permitted without written consent of the publisher

\section{INTRODUCTION}

Antarctic marine systems are characterized by 2 prominent features, low temperature and the markedly seasonal pattern of primary production, which in turn are 2 of the most important factors influencing the biology of marine organisms, especially growth rates and reproductive traits (Arnaud 1977, Clarke 1983, 1988, 1996, Dayton 1990, Pearse et al. 1991, StanwellSmith \& Peck 1998, among others).

Temperatures are low and very stable, ranging from -2 to $2^{\circ} \mathrm{C}$ in the maritime Antarctic (e.g. South Shetland Islands) and from -2 to $-1.5^{\circ} \mathrm{C}$ in the high Antarctic (Pearse et al. 1991). In spite of the slight seasonal variation of temperature, some biological processes such as larval developmental time and embryo viability showed sensitivity to even such slight variations (Hoegh-Guldberg \& Pearse 1995, Stanwell-Smith \& Peck 1998). In this sense, it has been argued that even reproductive seasonality could be triggered by temperature changes, a suggestion that it is based on the predictability of the change over the long evolutionary history of the Antarctic ecosystems (Pearse 1965, Pearse et al. 1991). On the other hand, the strong seasonal nature of energy input to the system has also been suggested as the driving force behind all seasonal processes in the Southern Ocean (Clarke 1988). In this sense, the value of temperature as a forcing variable for seasonality in biological processes is neglected, mainly because its variation is probably not 
biologically relevant (Clarke 1996). The relative importance of each factor is difficult to assess, since similar effects are predicted.

The seasonality of primary production may have a differential effect on different species, depending on how reliant they are on phytoplankton production. The biology, especially reproduction and growth, of Antarctic primary consumers might be coupled to primary production, while groups in higher levels of the food web, such as carnivores, detritivores, deposit feeders or necrophages, may be less tied to such seasonal pulses. Evidence supporting this hypothesis is still scarce. However, there are several examples of organisms which reproduce while being uncoupled from the pulses of primary production, in winter or even aseasonally, and the majority of these species are in higher levels of the food web than herbivorous or suspension feeders (Clarke 1988, Pearse et al. 1991, Stanwell-Smith \& Clarke 1998). A different approach to explain the mentioned patterns in reproductive cycles is based on developmental modes and energy requirements of larval stages rather than on adult food necessities. Pearse et al. (1991) predicted that invertebrates with planktotrophic larvae might reproduce in a manner tied to phytoplankton blooms, while brooders or those with lecithotrophic larvae would be released from primary production pulses and reproduce uncoupled to these pulses. The available information on suspension feeders is scarce and seems to show a clear seasonal pattern closely tied to phytoplankton production (Barnes \& Clarke 1998, Orejas et al. 2002). This work is focused on the reproductive ecology of a sessile suspension feeder, the solitary ascidian Cnemidocarpa verrucosa.

Ascidians are an exclusively marine taxon with a cosmopolitan distribution from rocky shores to muddy bottoms of abyssal plains. They are sessile suspension feeders, which exhibit solitary or modular growth and are important members of many benthic communities (Millar 1971, Abbott 1975, Turon 1990). The majority of solitary ascidians are oviparous (external fertilization), while colonial forms are usually ovoviviparous (internal fertilization) and larvae of both groups are lecithotrophic (Svane \& Young 1989). Reproductive patterns in the group range from 1 or 2 annual peaks in cold water and temperate species, to more or less continuous reproduction throughout the year in warm water species (Durante \& Sebens 1994). Even within some species with a wide latitudinal distribution, the reproductive pattern of temperate and warmer water populations can differ distinctly (Millar 1971). Reproductive seasonality in ascidians has been related to temperature changes generally (Millar 1971, Svane \& Young 1989, Durante \& Sebens 1994), but other factors that covary with temperature, such as primary production and photoperiod, have also been considered (Yamaguchi
1975, Becerro \& Turon 1992, Bingham 1997). Unfortunately, studies identifying direct links between such factors and ascidian reproduction are lacking so far.

In general, ascidians are important components of the Antarctic benthic fauna (Kott 1971, Kirkwood \& Burton 1988, Arntz et al. 1994, Saiz-Salinas et al. 1997, Starmans et al. 1999) and in some shallow areas, such as Potter Cove, King George Island, they are one of the dominant groups of the macrobenthic community (Sahade et al. 1998). Despite their numerical significance in the Antarctic system, ascidians have received scientific attention only recently, with studies on biochemical composition and chemical defense (McClintock et al. 1991), filtration rates (Kowalke 1999), respiration (Kowalke et al. 2001) and feeding ecology (Tatián et al. 2002); the last example is the only one made on a year-round basis.

Cnemidocarpa verrucosa is one of the most conspicuous, abundant, and well-studied Antarctic ascidians; it shows a circumpolar distribution in the Antarctic and sub-Antarctic (Kott 1971, Monniot \& Monniot 1983), and is very abundant in Potter Cove (Sahade et al. 1998, Tatián et al. 1998). The goal of this study was to assess whether reproduction of $C$. verrucosa in shallow waters is continuous, as to be expected from the lecithotrophic nature of ascidian larvae and/or the low annual temperature amplitude, or whether it peaks in summer, as to be expected from the distinct seasonality of primary production in Antarctica. We studied (1) prevalence of immature and mature gametes throughout the year, (2) annual patterns of gamete size, and (3) annual patterns of investment in reproduction.

\section{MATERIALS AND METHODS}

This work was conducted at Potter Cove, King George Island, South Shetland Islands, Antarctica $\left(62^{\circ} 14^{\prime} \mathrm{S}, 58^{\circ} 39^{\prime} \mathrm{W}\right)$, where the Argentinean Antarctic base Jubany and the German-Argentinean Dallmann Laboratory are situated (Fig. 1). Potter Cove is an inlet close to the entrance of Maxwell Bay, one of the 2 main fjords at King George Island. Water temperature varies from -2.0 to $1.4^{\circ} \mathrm{C}$, and salinity is ca. 33.9 PSU throughout the year. The water column is completely mixed except in spring/summer when a shallow thermocline may develop and melt-water run-off may cause a lowsalinity (down to $30.9 \mathrm{PSU}$ ) surface layer of up to $5 \mathrm{~m}$ (Schloss et al. 1999).

Potter Cove presents 3 different substrate types, hard bottoms in the outer cove dominated by solid rock, boulders, cobble, pebble and gravel, moraine deposits in the northern inner cove and soft bottom, mainly silt and clay, in the southern inner cove. The solitary species Cnemidocarpa verrucosa and Molgula peduncu- 


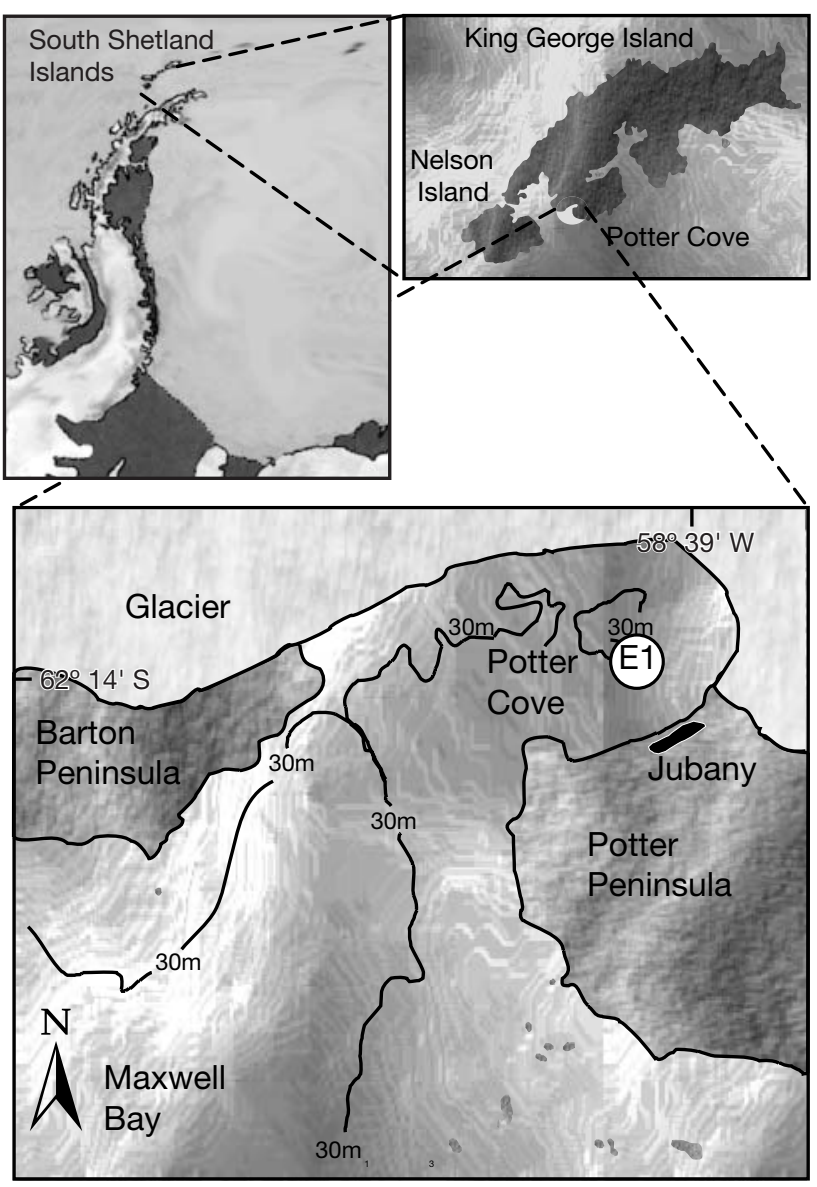

Fig. 1. Map of Potter Cove, King George Island, showing sampling location (E1). Oceanographic data, chlorophyll and temperature were taken at this site

lata and the colonial Aplidium radiatum are the only ascidians that inhabit the 3 substrate types available in the Cove. C. verrucosa showed densities ranging from 2 to 4 ind. $\mathrm{m}^{-2}$ and biomasses varying between 18 and $35 \mathrm{~g} \mathrm{DM} \mathrm{m}^{-2}$ (dry mass) at $30 \mathrm{~m}$ depth (Sahade 1999).

In order to study the annual pattern of reproduction of Cnemidocarpa verrucosa, samples were collected to determine (1) the prevalence of immature and mature gametes throughout the year, and annual patterns of gamete size, and (2) annual patterns of investment in reproduction. The first set of samples was collected monthly between January 1996 and March 1997 by SCUBA diving. Five individuals were collected, measured, dissected, and the gonads fixed in $2.5 \%$ formaldehyde in seawater for histological analysis. This tissue was then embedded in paraffin, sectioned along the 2 major perpendicular axes (gonads are nearly cylindrical) to avoid bias due to possible heterogeneity in the development within the ovary, and stained with hematoxylin-eosin. A whole section (8 to $10 \mu \mathrm{m})$ of each gonad was examined by microscope and the dia- meter of each oocyte that appeared sectioned through the nucleolus was measured, to a total of 100 oocytes in each gonad. The oocytes were classified by developmental stages into 3 classes: pre-vitellogenic $(<100 \mu \mathrm{m})$, vitellogenic $(<200 \mu \mathrm{m})$ and mature $(>200 \mu \mathrm{m})$ (oocyte size including accessory cells) (Grant \& Tyler 1983, Becerro \& Turon 1992). Maturity of testes was also noted and classified in 4 categories of male follicle development from 1 (immature) to 4 (mature) following Becerro \& Turon (1992).

The second set of samples was carried out to determine gonad indices. Five individuals per month were collected between January 1996 and June 1997, measured, and dry weight of the main organs (tunic, mantle, branchial sac, gut, and gonads) was determined after $48 \mathrm{~h}$ of lyophylisation. The gonad index (in percentage, GI) was calculated as the ratio of gonad mass to total animal mass (except gonads).

In order to test whether there were significant variations in mean oocyte size and GI throughout the year, and whether these variables could be related to temperature, chl a levels and individual sizes, analysis of covariance (ANCOVA), using months as factor and temperature, chl $a$ and body length as covariates, were performed. When means were different, StudentNewman-Keuls multiple comparison procedure was used to identify which months were different (Underwood 1997). Temperature and chl a data were obtained in the water column between 20 and $30 \mathrm{~m}$ depth from a long-term monitoring program running at Potter Cove.

Interannual variability in percentage of oocyte classes, mean oocyte diameter, GI, chl a standing stock and temperature of the 2 summer periods studied were analyzed using $t$-tests and pooling the samples from January to April of each summer. Homogeneity of variances was tested, in all cases, using Cochran's $C$-test; when variances were not homogeneous data were $\log _{10}(x+0.1)$-transformed, and homogeneity achieved after the transformation (Underwood 1997).

Due to logistic problems, samples from some months are missing: March, July, September, October and December 1996 are lacking in the histological sample set, and March, April, May, July, September, October and December 1996 and February 1997 are lacking from the GI sample set.

\section{RESULTS}

All individuals of Cnemidocarpa verrucosa sampled were sexually mature, except one that was considerably smaller and was not included in the analyses. $C$. verrucosa showed between 2 and 4 almost cylindrical gonads per individual. The female portion was situated in the medular position of the gonads whereas male 

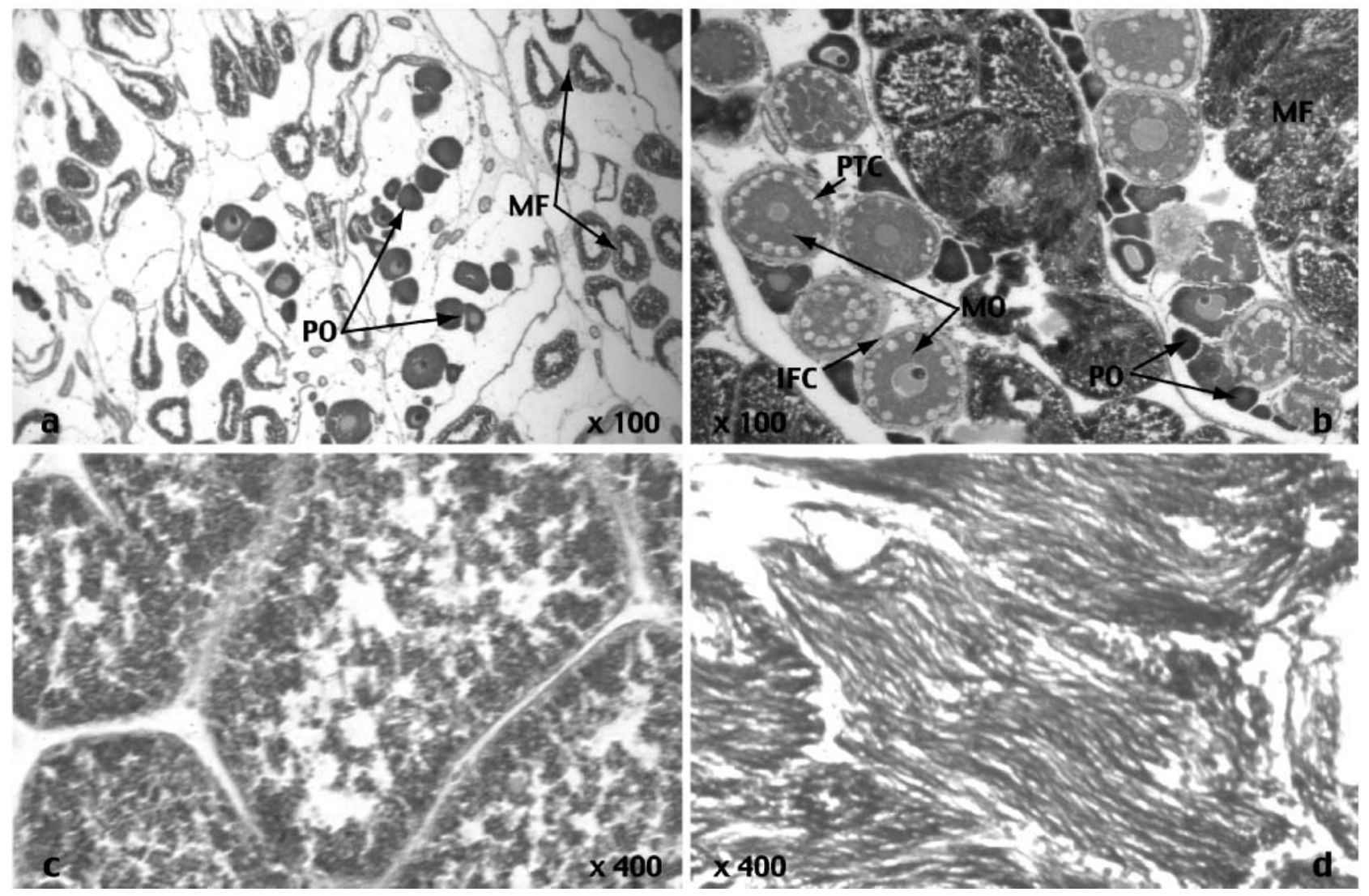

Fig. 2. Cnemidocarpa verrucosa. Gonadal histology. (a) Gonad after the reproductive peak, showing some pre-vitellogenic oocytes (PO) not larger than $100 \mu \mathrm{m}$; follicular cells are not visible yet. Male follicles (MF) are reduced and almost empty, only germinal cells are present. (b) Gonads before spawning, packed with fully mature oocytes (MO); inner follicular cells (IFC) are visible and completely developed, pseudo test cells (PTC), empty pockets near the cortex, are also visible. Note male follicles showing developed spermatocytes. (c) Male follicles showing immature spermatocytes, classified as Class 1. (d) Completely developed spermatozoans, classified as Class 4

follicles were situated in the cortical portion. This pattern was observed throughout the year, with no variation in the external aspect of the gonads. Histological observations revealed, however, clear differences between mature gonads (filled with fully vitellogenic oocytes and developed spermatocytes) and the spent condition (gonads with a few immature oocytes and almost empty male follicles; Fig. 2).

There was a distinct relationship between oocyte diameter and development stage: oocytes $<100 \mu \mathrm{m}$ were immature and did not show any yolk (previtellogenic), oocytes between 100 and $200 \mu \mathrm{m}$ underwent vitellogenesis (vitellogenic), whereas oocytes $>200 \mu \mathrm{m}$ appeared fully mature and surrounded by developed inner-follicular cells (mature) (Fig. 2a). Some samples were examined by transmission electron microscopy (TEM), which showed that vitellogenic and mature oocytes stored huge amounts of yolk granules as well as traces of glycogen, and also made it possible to determine that test cells are absent in this species, but empty structures called 'pseudo test cells' were observed in the cortex from the beginning of the vitellogenesis (Fig. 3). Testis maturity appeared to be simultaneous all over the gonad. Class 1 of male gametes represented the first stage in spermatogenesis, without an apparent tail (Fig. 2c), whereas Class 4 follicles represented the mature spermatocytes with the tail completely developed (Fig. 2d). Classes 2 and 3 represent intermediate developmental stages.

Oocyte class distribution showed a distinct annual cycle (Fig. 4). Pre-vitellogenic oocytes were present year-round, but in higher percentages in spring and summer. Vitellogenic oocytes were especially abundant in winter, peaking in June and showing a sharp decrease in August. Mature oocytes were observed in February, May, June and August during 1996 and February and March in 1997, but were more abundant during winter, particularly in May and June, being nearly absent in August, when only pre-vitellogenic oocytes were found. Only in June did all the individu- 

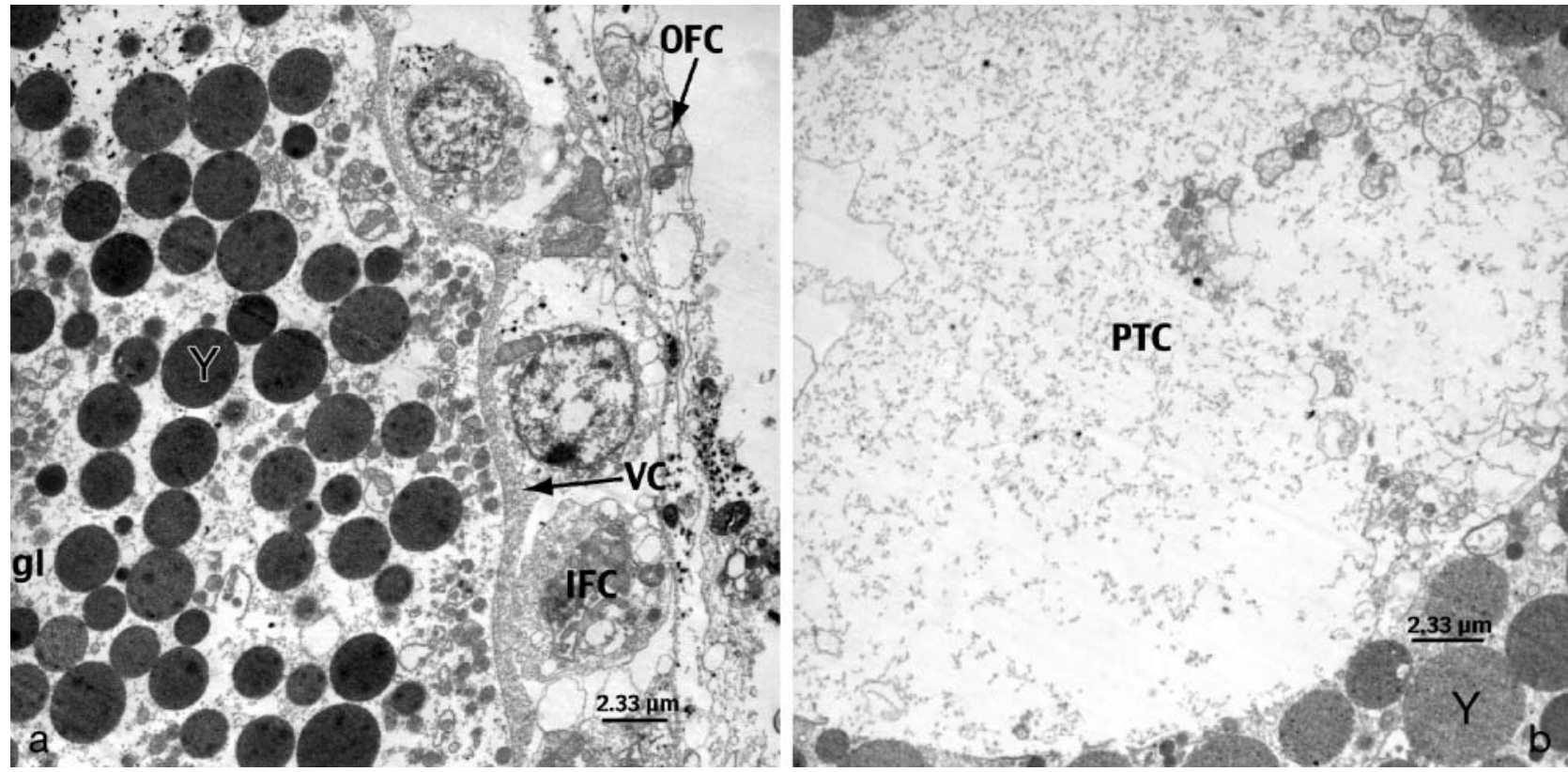

Fig. 3. Cnemidocarpa verrucosa. Transmission electron microscopy (TEM) images of a mature oocyte. (a) Oocyte showing the complex envelopes characteristic of ascidians: note the inner and outer follicular cells (IFC and OFC, respectively) and the vitelline coat (VC), while test cells are absent in this species. The cytoplasm is filled with yolk granules (Y) and glycogen (gl) traces are also present $(\times 3000)$. (b) Detail of a pseudo test cell $($ PTC) in the cortex of the oocyte and surrounded by yolk granules $(\times 7000)$

als contain mature oocytes, while at other months only 1 to 3 of the 5 individuals sampled had mature oocytes. The development of male gametes was gradual; mature spermatocytes occurred simultaneously with the mature oocytes but were present only in June (Fig. 4).

Mean oocyte size showed significant variation during the studied cycle, and no effect of body length, chl a levels or temperature was found (Table 1). A slight increase in oocyte size from summer to winter was observed, reaching a clear peak in June, which was followed by a sharp decrease in August (Fig. 5). The seasonal development of the GI coincided with oocyte and spermatocyte development cycles (Fig. 5). ANCOVA of GI showed the same trend of mean oocyte size, sampling data showed significant effects, while body length, chl a levels and temperature (covariates) were not related to GI (Table 1). A second peak in GI during April and May 1997 could not be confirmed by oocyte development, as synoptic histological data were missing.

The 2 summer seasons examined, pooling data from January to April, showed differences in the percentages of pre-vitellogenic and vitellogenic oocytes and mean oocyte diameter, as well as in chl $a$, while there were no differences in the percentage of mature oocytes and GI (Table 2). Vitellogenic oocytes, mean oocyte size, GI and chl a were higher in summer 1997, while pre-vitellogenic oocytes were more abundant in 1996.
Fig. 4. Cnemidocarpa verrucosa. Seasonal variation of mean percentages of each oocyte class at Potter Cove. Bars represent SDs. Numbers in the upper squares indicate the mode of male follicle development (n ranged from 4 to 6 ) 
Table 1. Cnemidocarpa verrucosa. (a) ANCOVA of oocyte sizes and gonadal indices testing for differences among sampling dates, examining possible relationships with chl a levels, temperature, and size of individuals (body length). (b) A posteriori test using the StudentNewman-Keuls procedure to identify the sampling dates that caused differences in the ANCOVA

\begin{tabular}{|c|c|c|c|c|c|c|c|c|}
\hline \multicolumn{2}{|l|}{ (a) } & & $\mathrm{df}$ & SS & \multicolumn{2}{|c|}{ MS } & $F$-ratio & $\mathrm{p}$ \\
\hline \multicolumn{9}{|c|}{ Oocyte diameter } \\
\hline \multicolumn{9}{|l|}{ Covariate } \\
\hline \multicolumn{2}{|l|}{ Chl a } & & 1 & 1972.61 & \multicolumn{2}{|c|}{1972.61} & 3.18 & 0.08 \\
\hline \multicolumn{2}{|c|}{ Temperature } & & 1 & 1417.37 & \multicolumn{2}{|c|}{1417.37} & 2.29 & 0.14 \\
\hline \multicolumn{2}{|c|}{ Body length } & & 1 & 37.52 & \multicolumn{2}{|c|}{37.52} & 0.06 & 0.81 \\
\hline \multicolumn{9}{|l|}{ Main factor } \\
\hline \multirow{2}{*}{\multicolumn{3}{|c|}{$\begin{array}{l}\text { Sampling dates } \\
\text { Residual }\end{array}$}} & 9 & 39351.8 & \multicolumn{2}{|c|}{4372.42} & \multirow[t]{2}{*}{7.06} & \multirow[t]{2}{*}{$<0.01$} \\
\hline & & & 34 & 21065.2 & 619 & & & \\
\hline \multicolumn{3}{|l|}{ Total } & 46 & \multicolumn{3}{|l|}{63844.5} & & \\
\hline \multicolumn{9}{|l|}{ GI } \\
\hline \multicolumn{9}{|l|}{ Covariate } \\
\hline \multicolumn{2}{|l|}{ Chl a } & & 1 & 1.32 & 1.3 & & 0.35 & 0.56 \\
\hline Temperatu & & & 1 & 4.73 & 4.7 & & 1.27 & 0.27 \\
\hline Body leng & & & 1 & 0.39 & 0.3 & & 0.10 & 0.75 \\
\hline Main factor & & & & & & & & \\
\hline Sampling & & & 8 & 165.41 & 20. & & 5.53 & $<0.01$ \\
\hline Residual & & & 32 & 119.60 & 3.7 & & & \\
\hline Total & & & 43 & 356.65 & & & & \\
\hline (b) Student- & $\mathbf{w n}$ & Ian- & -Keu & multiple & ompa & son & proced & ure \\
\hline Ooc & di & me & ter & & & G. & & \\
\hline Month & & & roup & $\mathrm{M}$ & nth & & Group & \\
\hline Jan 96 & $\mathrm{a}$ & & & & v 96 & $\mathrm{a}$ & & \\
\hline Feb 96 & a & $\mathrm{b}$ & & $\mathrm{Au}$ & g 96 & $\mathrm{a}$ & & \\
\hline Nov 96 & a & $\mathrm{b}$ & & $\mathrm{Fe}$ & 96 & $\mathrm{a}$ & $\mathrm{b}$ & \\
\hline Aug 96 & a & $\mathrm{b}$ & & & 96 & $\mathrm{a}$ & $\mathrm{b}$ & \\
\hline Apr 96 & a & $\mathrm{b}$ & $\mathrm{C}$ & & 97 & $\mathrm{a}$ & $\mathrm{b}$ & \\
\hline Jan 97 & & $\mathrm{~b}$ & C & $\mathrm{M}$ & r 97 & $\mathrm{a}$ & $\mathrm{b}$ & \\
\hline Mar 97 & & $\mathrm{~b}$ & C & $\mathrm{Ju}$ & 96 & & C & d \\
\hline Feb 97 & & $\mathrm{~b}$ & C & $\mathrm{M}$ & y 97 & & C & d \\
\hline May 96 & & & c & Ap & 97 & & & d \\
\hline Jun 96 & & & & d & & & & \\
\hline
\end{tabular}

Table 2. Cnemidocarpa verrucosa. Comparison of several variables of the 2 summer seasons studied using Student's $t$-test. Data were pooled from January to March; in the case of chl a December was pooled as well. $\mathrm{H}_{0}$ : null hypothesis; $\mathrm{H}_{\mathrm{A} 1}$ and $\mathrm{H}_{\mathrm{A} 2}$ : alternative hypotheses

\begin{tabular}{|lrrccc|}
\hline & df & $t$ & $\begin{array}{c}\mathrm{H}_{0} \\
\prime 96=' 97\end{array}$ & $\begin{array}{c}\mathrm{H}_{\mathrm{A} 1} \\
\text { '96 }>\text { '97 }\end{array}$ & $\begin{array}{c}\mathrm{H}_{\mathrm{A} 2} \\
\text { '96 }<\text { '97 }\end{array}$ \\
\hline Previtellogenic oocytes & 26 & 4.72 & $\mathrm{p}<0.01$ & $\mathrm{p}<0.01$ & $\mathrm{p}=0.99$ \\
Vitellogenic oocytes & 26 & -4.92 & $\mathrm{p}<0.01$ & $\mathrm{p}=0.998$ & $\mathrm{p}<0.01$ \\
Mature oocytes & 26 & -0.57 & $\mathrm{p}=0.57$ & & \\
Oocyte diameter & 26 & -4.69 & $\mathrm{p}<0.01$ & $\mathrm{p}=0.99$ & $\mathrm{p}<0.01$ \\
GI & 16 & -1.77 & $\mathrm{p}=0.09$ & & \\
Chl a & 49 & -2.13 & $\mathrm{p}<0.05$ & $\mathrm{p}=0.987$ & $\mathrm{p}<0.05$ \\
Temperature & 49 & 0.92 & $\mathrm{p}=0.36$ & & \\
& & & & & \\
\hline
\end{tabular}

\section{DISCUSSION}

The permanent stations in Antarctic coastal areas allowed an important development in autoecological and year-round-based studies, as well as long-term monitoring programs of environmental and biological variables. Despite this, an important fraction of this work has been devoted to reproduction studies in a wide variety of taxa and, based on year-round data, the majority were done on organisms situated in higher levels of the food web than filter feeders (see Pearse et al. 1991). This is surprising, since Antarctic benthic communities are often characterized and dominated by suspension feeders such as sponges, bryozoans, some cnidarians and ascidians (Dayton 1990, Arntz et al. 1994, Starmans et al. 1999, Gili et al. 2001). Except for the work of Barnes \& Clarke (1998) with bryozoans, and that of Orejas et al. (2002) with gorgonians, little information exists on reproductive traits and seasonality of these groups. Therefore, the present work provides the first year-round study of the reproductive ecology of an ascidian species, one of the most important faunal groups of Antarctic benthic communities.

\section{Seasonality of reproduction}

The patterns exhibited by the presence of (1) mature oocytes and mature spermatocytes, (2) mean oocyte sizes, and (3) GI clearly suggest that reproduction in Cnemidocarpa verrucosa at Potter Cove is seasonal, spawning in the Austral winter and with 1 oocyte generation per year.

Mature oocytes were more abundant in winter, especially in June, while mature spermatozoa were only present in June. The rest of the cycle and, except for 1 individual in August, mature spermatocytes were not observed, thus restricting reproduction to June-July when both gametes were mature. This idea is also supported by the spent condition observed in the gonads of the majority of individuals in August, indicating that spawning took place very probably during July.

Mean oocyte size and GI showed a clear peak in winter and significant differences throughout the year, as indicated by ANCOVA, which also showed that the observed differences were independent of specimen size and, particularly important, of temperature and chl a levels in the water column. This lack of analytical correlation with the environmental variables analyzed is 

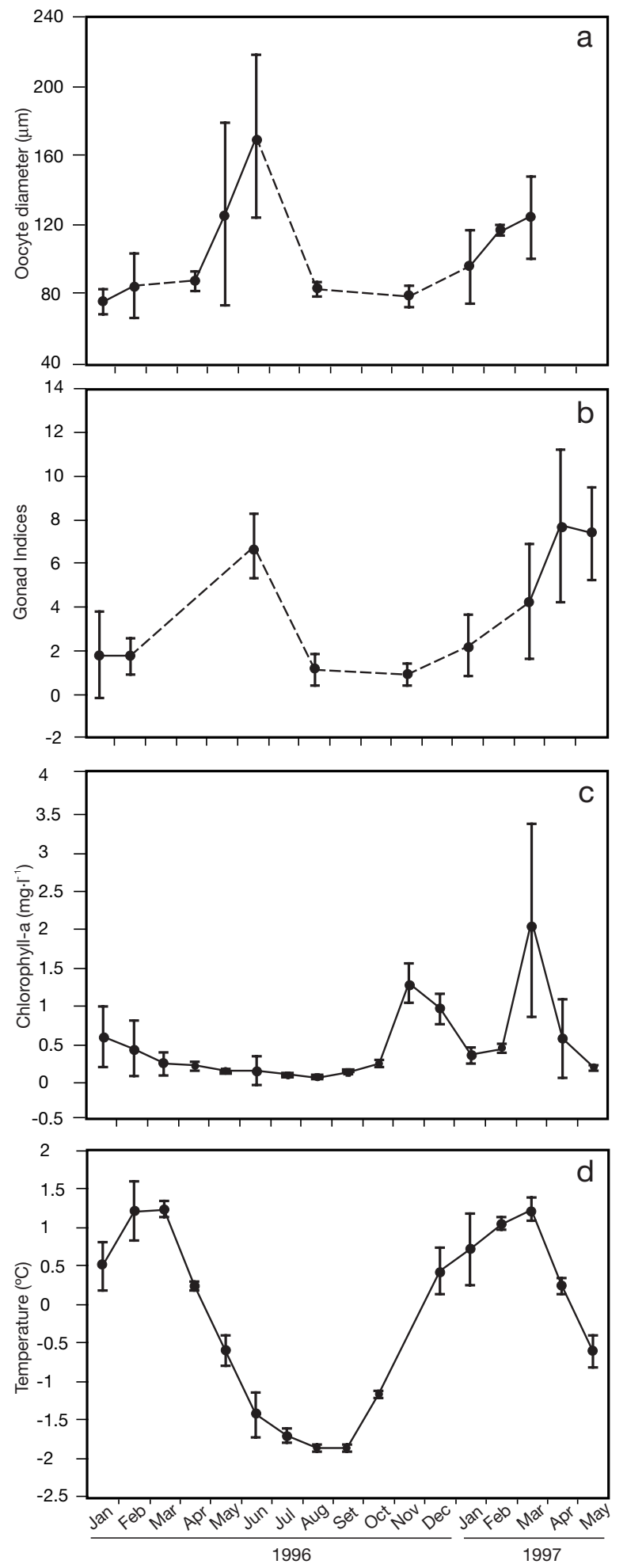

Fig. 5. Cnemidocarpa verrucosa. $(\mathrm{a}, \mathrm{b})$ Seasonal variations of oocyte diameter and GI, respectively. Data are means and SDs; dashed lines indicate discontinuity in data (n ranged from 4 to 6). (c,d) Chl a concentrations and temperature, respectively, at Potter Cove; means of data taken between 20 and $30 \mathrm{~m}$ depth in the water column, with bottom at $33 \mathrm{~m}$; bars are SDs also confirmed graphically (Fig. 5), which also indicates agreement between both methods. The use of GI is widespread in studies of reproductive cycles of marine invertebrates. Although they are easier and faster to do, they provide less precision than histological quantitative methods. Coupling both methods is useful to test whether the GI actually reflects reproductive status or not, thus facilitating further assessment of reproductive stages in the group or species, whenever they showed a positive correlation to the histological observations. In ascidians, Becerro \& Turon (1992) have applied both methods to Halocynthia papillosa and Microcosmus sabatieri, and GI showed a similar pattern of mean oocyte diameter variations. In this case, the data indicate that the GI is useful for further studies of reproductive cycles, also on Cnemidocarpa verrucosa or related species (e.g. same family).

The reproductive seasonality exhibited by Cnemidocarpa verrucosa during the austral winter is striking, since this is the period with lowest energy available in the system. Data taken in a long-term study at Potter Cove showed that for several years chlorophyll levels (including nano- and picoplankton) during winter have been near the limits of detection and even low, compared with other Antarctic areas, in summer (Schloss 1997, Kowalke 1999, Schloss et al. 1999, Tatián et al. 2002). Moreover, in a parallel study, using the same individuals as in the present work, the stomachs of $C$. verrucosa had low fullness indices during winter and were nearly empty in June (Tatián et al. 2004).

It has been suggested that Antarctic benthic invertebrates that reproduce via lecithotrophic larvae should be released from the high seasonality of primary production characteristic of Antarctic system, and therefore they may be able to reproduce aseasonally (Pearse et al. 1991). Nevertheless, this perspective is mainly based on nutritional and resource necessities of the larval stage. A different image could arise when the complete life-cycles are taken into account; then energetic requirements of adults, to allocate for reproduction, can be as important as that of larvae, since all the energy used by lecithotrophic larvae must be provided by the parent. Thus, it should be expected that reproduction, especially in herbivores and suspension feeders, should be geared to primary production pulses (Clarke 1988).

Although many Antarctic invertebrates reproduce throughout the year or during winter, they posses features that give them the possibility to cope with the low energy period during winter. Omnivorous, carnivorous, scavenging and necrophagous species, such as some amphipods, isopods, asteroids, nemerteans and other groups, which are in higher levels of the food web than suspension feeders (see Clarke 1988 and 
Pearse et al. 1991), utilize food sources that may be quite constant, and therefore the energetic limitation during winter should be not so severe, at least compared with those that directly depend on the periodic pulses of primary production. Other organisms such as the echinoid Sterechinus neumayeri (Pearse \& Giese 1966) and the gorgonian Ainigmaptilion antarticum (Orejas et al. 2002) have extended gametogenesis of 18 to $24 \mathrm{mo}$; in this way, the storage of material for reproduction can cover 2 summers when energy is diverted to gonad production, interspersed with one winter when it is not. In these cases, 2 cohorts of oocytes develop simultaneously. A different strategy involves energy storage in some specific organ during the period of food availability, which will further be used to fuel gameto- and vitellogenesis. This is the case of some asteroids like Odontaster validus, which stores energy in the pyloric caeca that can be later allocated for reproduction (Pearse 1965, StanwellSmith \& Clarke 1998). This storage of reserves does not seem to be an extended feature among Antarctic benthic invertebrates, contrary to their planktonic counterparts that usually exhibit extensive lipid reserves (Clarke 1988).

Benthic organisms that reproduce aseasonally or during winter often possess a combination of strategies: Odontaster validus has an oogenesis period of 18 to $24 \mathrm{mo}$, several modes of feeding including suspension feeding, scavenging and active predation, and also stores energy in the pyloric caeca (Pearse 1965). In the case of Cnemidocarpa verrucosa, none of these features, at first sight, appears to be present; the reproductive period takes no more than $12 \mathrm{mo}$, it is a suspension feeder, and the storage of energy reserves to fuel reproduction or even to survive a starvation period has not been reported in solitary ascidians. Moreover, lecithotrophic ascidian larvae are short-lived (a few minutes to a maximum of $2 \mathrm{wk}$, Burighel \& Cloney 1997), which means that new recruits are established in a low-energy environment. Thus, one could ask why and how they are reproducing during winter.

The reproductive strategy exhibited by Cnemidocarpa verrucosa that at first sight could appear as disadvantageous, at least in energetic terms, seems to be ecologically successful; this ascidian is one of the dominant species at Potter Cove (Sahade et al. 1998, Sahade 1999) and one of the most conspicuous ascidian species around Antarctica (Kott 1971, Monniot \& Monniot 1983). In this sense, reproduction in winter could be related to avoidance of larval predation, since possible predators are more abundant in the summer season and in the outer area of Potter Cove (Fuentes pers. comm.). Whether this is a phylogenetically fixed trait or a local ecological strategy for this species in the maritime Antarctic, or even for Potter Cove popula- tions, is still an open question. However McClintock et al. (1991) found a few specimens of Cnemidocarpa verrucosa spawning in November at McMurdo Sound, which could suggest different local strategies.

It is not clear how Cnemidocarpa verrucosa reproduces in winter; perhaps winter is not really a stress period of food availability, or C. verrucosa is able to store some reserves to be further used in reproduction. The extended low levels of pelagic primary production at Potter Cove year-round would suggest other, local or allochthonous, energy sources, i.e. benthic production, bacterial communities, detritus, or DOC (dissolved organic matter), which could be available for extended periods or even year-round, not only for the reproduction of this species but also to keep the rich benthic system present in Potter Cove (Sahade 1999). However, the nearly empty stomachs of $C$. verrucosa in June show that this is a period of low food availability, which, in turn, supports the hypothesis that C. verrucosa may store some reserves during summer to fuel the further reproductive cycle (probably a function of the abundant endocarps in this species); however, with only 15 mo of data, little more can be said.

\section{Interannual variability}

Although this study covered only 15 mo, it allowed the comparison of 2 summer seasons. Significant differences were found on most of the reproductive aspects analyzed in Cnemidocarpa verrucosa, the exceptions being the percentage of mature oocytes and GI. This can be explained because summer is not the reproductive season; however, mean oocyte sizes and the percentage of vitellogenic oocytes were higher in 1997 than in 1996. A similar pattern showed that chlorophyll concentrations were higher in 1997 than in 1996, while there were no differences in temperature. Although GI did not show differences between the 2 summer seasons, in 1997 the peak was higher than in 1996, and was also earlier, in April to May. Unfortunately it is not possible to discriminate whether the reproductive season was advanced in 1997 compared with 1996, or if in 1997 there was a higher reproductive output and the real peak in GI was not reached until May (last month sampled).

Despite the short period covered by this study and the speculative character of the contributions that could be made on an inter-annual basis, it is consistent with the increasing reports of inter-annual environmental variability and biological processes in the Antarctic ecosystem (Murphy et al. 1995, Clarke \& Leakey 1996). This points out the necessity to focus on the ecological role played, not only by summer-winter differences, but also by inter-annual variability. 


\section{Comparison with other ascidian species}

All individuals that showed mature sperm also had mature oocytes, indicating that Cnemidocarpa verrucosa is a simultaneous hermaphrodite. Vitellogenesis was especially active in winter, and TEM observations showed high amounts of yolk in vitellogenic and mature oocytes, and also confirmed the absence of the characteristic test cells, common to nearly all ascidian species. Test cells are located under the vitelline coat in vitellogenic oocytes, and the function attributed to these cells includes nourishment of oocytes, transfer of vanadium, secretion of the vitelline coat, and the secretion of products onto the outer cuticular layer of the larval tunic to make them hydrophilic (Burighel \& Cloney 1997). Only a few ascidian species, such as Molgula pacifica, lack these cells (Cloney 1995) and none are styelids, except Cnemidocarpa verrucosa. $C$. irene from the tropics and C. finmarkiensis from temperate waters both have large test cells which are free in the perivitelline space of mature oocytes (C. Lambert unpubl. obs.), thus, the absence of test cells is not an inclusive trait of the genus.

Ascidians exhibit a wide range of patterns in their reproductive cycles, going from continuous gamete release throughout the year (Lambert 1968) to a strictly seasonal spawning per year. Temperature has been considered to be the major regulating factor determining the seasonality of gamete production and release, thus, geographic location and depth (which influence water temperature) could determine whether reproduction takes place year-round or only during the warm season (Millar 1971, Svane 1984, Durante \& Sebens 1994). Generally, ascidians inhabiting warmer regions present extended reproductive cycles, while those inhabiting areas with a clear seasonal pattern in water temperature exhibit a reproductive seasonality coupled with higher annual temperatures. This pattern can also be displayed by a species with a wide latitudinal distribution, as in Botryllus schlosseri, in which high-latitude populations reproduce during summer and low-latitude populations extend the reproductive period year-round (Millar 1971). Nevertheless, there are other factors that present the same variation pattern as those of temperature, particularly in tropical and temperate waters, such as phytoplankton production or photoperiod. These effects are difficult to separate from those caused by temperature, except when they are decoupled. This could be the case for the ascidians Hallocynthia papillosa and Microcosmus sabatieri, which reproduce in the Mediterranean sea after the period of highest temperatures in the area, but coincident with higher phytoplankton production (Becerro \& Turon 1992).
Although photoperiod can be an important factor, especially triggering spawning in ascidians (Svane \& Young 1989, Bingham 1997), it has also demonstrated its importance as a gametogenesis regulator in the Antarctic sea star Odontaster validus (Pearse \& Bosh 2002). In this particular population of Cnemidocarpa verrucosa at Potter Cove, the importance of photoperiod is very difficult to evaluate because during summer there is nearly no light below $5 \mathrm{~m}$ depth due to the sediments discharged by creeks into the cove, and in winter light levels are dependent on the pack-ice conditions. Therefore it is very probable that it does not play an important role in this case.

There is little information on reproduction in the genus Cnemidocarpa, and some observations indicate that in tropical areas (Guam) C. irene is either a winter or all-year spawner, while in temperate areas (Friday Harbor Washington) C. finmarkiensis is at least a summer spawner or even a year-round spawner (C. Lambert unpubl. obs.).

Neither temperature variations nor chlorophyll concentrations appeared to be directly related to Cnemidocarpa verrucosa reproductive seasonality at Potter Cove. However, it is tempting to match the higher gonad production in 1997 with the higher chlorophyll concentrations registered that year than in the 1996 summer season. Although local primary production would not be the main energy source in Potter Cove, as discussed above, these results suggest that local chlorophyll levels could reflect favorable production conditions in adjacent areas, or for benthic macroagal production, which would in turn provide the energy to the Potter Cove ecosystem.

Acknowledgements. We thank the members of Jubany Station (1996-1997) for their assistance, especially to our dive companions O. Rillos, A. Fernández and Jensito. We are grateful to K. Beyer for her help with TEM observations. Financial and logistic supports were provided by CONICET, Instituto Antártico Argentino and Alfred Wegener Institut. We are especially grateful to Dave Barnes, Charles Lambert (also for providing his data), John Pearse, Tom Brey, Miriam Fernández, Rudy Herman, Cova Orejas and an anonymous referee whose comments greatly improved earlier versions of this manuscript. We also want to thank to Wolf Arntz for his constant support.

\section{LITERATURE CITED}

Abbott DP (1975) Phylum Chordata: introduction and Urochordata. In: Smith RI, Carlton JT (eds) Lights manual: intertidal invertebrates of the central California coast, 3rd edn. University of California Press, Berkeley, p 638-655

Arnaud PM (1977) Adaptations within the Antarctic marine ecosystem. In: Llano GA (ed) Adaptations within Antarctic ecosystems. Proc SCAR Biol Symp 1974. The Smithsonian Institution, Washington, DC, p 135-157

Arntz WE, Brey T, Gallardo VA (1994) Antarctic zoobenthos. Oceanogr Mar Biol Annu Rev 32:241-304 
Barnes DKA, Clarke A (1998) Seasonality of polypide recycling and sexual reproduction in some erect Antarctic bryozoans. Mar Biol 131:647-658

Becerro M A, Turon X (1992) Reproductive cycles of the ascidians Microcosmus sabatieri and Halocynthia papillosa in the Northwestern Mediterranean. Mar Biol 13:363-373

Bingham BL (1997) Light cycles and gametogenesis in three temperate ascidian species. Invert Rep Dev 116:61-70

Burighel P, Cloney RA (1997) Urochordata: Ascidiacea. In: Harrison FW, Ruppert EE (eds) Microscopic anatomy of invertebrates, Vol 15. Wiley-Liss, New York, p 221-347

Clarke A (1983) Life in cold water: the physiological ecology of polar marine ectotherms. Oceanogr Mar Biol Annu Rev 21:341-453

Clarke A (1988) Seasonality in the Antarctic marine environment. Comp Biochem Physiol 90B:461-473

Clarke A (1996) Marine benthic populations in Antarctica: patterns and processes. In: Ross RM, Hofmann EE, Quetin LB (eds) Foundations for ecological research west of the Antarctic peninsula. Antarct Res Ser 70:373-388

Clarke A, Leakey RJG (1996) The seasonal cycle of phytoplankton macronutrients and the microbial community in a nearshore Antarctic marine ecosystem. Limnol Oceanogr 41:1281-1294

Cloney RA (1995) Origin and differentiation of the inner follicular cells during oogenesis in Molgula pacifica (Urochordata), an ascidian without test cells. Acta Zool 76:89-104

Dayton PK (1990) Polar benthos. In: Smith WE (ed.) Polar oceanography. Part B. Chemistry, biology and geology. Academic Press, London, p 631-685

Durante KM, Sebens KP (1994) Reproductive ecology of the ascidians Molgula citrina Alder \& Hancock, 1848 and Aplidium glabrum (Verrill, 1871) from the Gulf of Maine, USA. Ophelia 39:1-21

Gili JM, Coma R, Orejas C, Lopez-Gonzales PJ, Zabala M (2001) Are Antarctic suspension-feeding communities different from those elsewhere in the world? Polar Biol 24: $473-485$

Grant A, Tyler PA (1983) The analysis of data in studies of invertebrate reproduction. I. Introduction and statistical analysis of gonad indices and maturity indices. Int J Invert Rep 6:259-269

Hoegh-Guldberg O, Pearse JS (1995) Temperature, food availability, and the development of marine invertebrate larvae. Am Zool 35:415-425

Kirkwood JM, Burton HR (1988) Macrobenthic species assemblages in Ellis Fjord, Vestfold Hills, Antarctica. Mar Biol 97:445-457

Kott P (1971) Antarctic Ascidiacea II. Antarct Res Ser 17:11-82

Kowalke J (1999) Filtration in Antarctic ascidians - striking a balance. J Exp Mar Biol Ecol 242:233-244

Kowalke J, Tatián M, Sahade R, Arntz WE (2001) Production and respiration of Antarctic ascidians. Polar Biol 24:663-669

Lambert G (1968) The general ecology and growth of a solitary ascidian, Corella willmeriana. Biol Bull 135:296-307

McClintock JB, Heine J, Slattery M, Weston J (1991) Biochemical and energetic composition, population biology, and chemical defense of the antarctic ascidian Cnemidocarpa verrucosa Lesson. J Exp Mar Biol Ecol 147:163-175

Millar RH (1971) The biology of ascidians. Adv Mar Biol 9:1-100

Monniot C, Monniot F (1983) Ascidies antarctiques et subantarctiques: morphologie et biogéographie. Mem Mus Natl Hist Nat Ser A Zool 125:1-135

Murphy EJ, Clarke A, Simon C, Priddle J (1995) Temporal variation in Antarctic sea-ice: analysis of a long term fastice record from the South Orkney Islands. Deep-Sea Res 42:1045-1062

Orejas C, López-González PJ, Gili JM, Teixido N, Gutt J,
Arntz WE (2002) Distribution and reproductive ecology of the Antarctic octocoral Ainigmaptilon antarcticum in the Weddell Sea. Mar Ecol Prog Ser 231:101-114

Pearse JS (1965) Reproductive periodicities in several contrasting populations of Odontaster validus Koehler, a common Antarctic asteroid. Antarct Res Ser 5:39-85

Pearse JS, Bosh I (2002) Photoperiodic regulation of gametogenesisin the Antarctic sea star Odontaster validus Koehler: evidence for a circannual rhythm modulated by light. Invert Rep Dev 41:73-81

Pearse JS, Giese AC (1966) Food, reproduction and organic constitution of the common Antarctic echinoid Sterechinus neumayeri (Meissner). Biol Bull 130:387-401

Pearse JS, McKlintock JB, Bosch I (1991) Reproduction of Antarctic benthic marine invertebrates: tempos, modes and timing. Am Zool 31:65-80

Sahade R (1999) Patterns and processes in an Antarctic epibenthic community: the case of Potter Cove. PhD thesis, University of Córdoba (in Spanish)

Sahade R, Tatian M, Kowalke J, Khüne S, Esnal GB (1998) Benthic faunal associations in soft substrates at Potter Cove, King George Island, Antarctica. Polar Biol 19:85-91

Sáiz-Salinas JI, Ramos A, García FJ, Troncoso JS, San Martín G, Sanz C, Palacin C (1997) Quantitative analysis of macrobenthic soft-bottom assemblages in South Shetland waters (Antarctica). Polar Biol 17:393-400

Schloss I (1997) Escalas temporo-espaciales de variabilidad del fitoplancton costero antártico. PhD thesis, University of Buenos Aires

Schloss I, Ferreyra G, Mercuri G, Kowalke J (1999) Potential food availability for benthic filter feeders in an Antarctic coastal shallow environment: a sediment trap study. Sci Mar 63:99-111

Stanwell-Smith D, Clarke A (1998) Seasonality of reproduction in the cushion star Odontaster validus at Signy Island, Antarctica. Mar Biol 131:479-487

Stanwell-Smith D, Peck LS (1998) Teperature and ebryonic developent in relation to spawning and field occurrence of larvae of three Antarctic echinoderms. Biol Bull 194:44-52

Starmans A, Gutt J, Arntz WE (1999) Mega-epibenthic communities in Arctic and Antarctic shelf areas. Mar Biol 135: $269-280$

Svane I (1984) Observations on the long-term population dynamics of the perennial ascidian Ascidia mentula O.F. Müller, on the Swedish west coast. Biol Bull 167:630-646

Svane I, Young CM (1989) The ecology and behaviour of ascidian larvae. Oceanogr Mar Biol Annu Rev 27:45-90

Tatián M, Sahade R, Doucet M, Esnal GB (1998) Ascidians (Tunicata, Ascidiacea) of Potter Cove, South Shetland Islands, Antarctica. Antarct Sci 10:147-152

Tatián M, Sahade R, Kowalke J, Kivatinitz SC, Esnal GB (2002) Food availability and gut contents in the ascidian Cnemidocarpa verrucosa at Potter Cove, Antactica. Polar Biol 25:58-64

Tatián M, Sahade R, Esnal GB (2004) Diet components in the food of Antarctic ascidians, living at low levels of primary production. Antarct Sci 16:123-128

Turon X (1990) Distribution and abundance of ascidians from a locality on the northeast coast of Spain. PSZN I: Mar Ecol 11:291-308

Underwood AJ (1997) Experiments in ecology. Their logical design and interpretation using analysis of variance. Cambridge University Press, Cambridge

Yamaguchi M (1975) Growth and reproductive cycles of the marine fouling ascidians Ciona intestinalis, Styela plicata, Botrylloides violaceus and Leptoclinum mitsukurii at Aburatsubo-Moriso Inlet (Central Japan). Mar Biol 29:253-259 